\title{
The Guilded Classroom: Using Gamification to Engage and Motivate Undergraduates
}

\author{
Julia Gressick $^{1}$ and Joel B. Langston ${ }^{2}$
}

\begin{abstract}
There is a breadth of psychological research that points to potential cognitive benefits of game play. Games engage and motivate learners while promoting mastery of skills and content knowledge. Further, thoughtfully applying gaming elements and structures to classroom environments, an approach called gamification, has the potential to optimize learning. This paper discusses theorydriven classroom gamification innovations implemented in an undergraduate educational psychology course and uses a case study approach to understand how these changes impacted students' in-class learning experiences in positive ways. We will discuss specific interventions, students' perceptions of these interventions, instructor reflection of the effects on student learning outcomes, and implications for classroom practice.
\end{abstract}

Keywords: Gamified, motivation, educational psychology, game-based learning, collaboration

The purpose of this paper is to describe a case of instructional innovation in an undergraduate educational psychology course guided by the principles of gamification, which involves applying game-based elements to non-game environments (Kapp, 2012). We examined the effectiveness of these approaches on student learning and student perceptions of these interventions. The instructional design approach we employed reflects the deep structures of games that motivate individuals and hold potential to promote student engagement and the development of enduring understanding.

In the following sections, we define gamification, review related literature, describe interventions based on the intersection of approach and theory, provide evidence of the effect of these initiatives on students' learning, and offer conclusions. This innovation was guided by the following question: How does thoughtful gamification influence student perceptions, engagement, and learning outcomes in an undergraduate educational psychology course?

\section{From Games to Gamification: The Benefits of Gamification}

There is a breadth of research on learning that points to the potential cognitive benefits of game play. Because of their design, games engage learners in a way that motivates and encourages perseverance (Gee, 2003). This is largely because games offload mistakes to the process of play in a way that minimizes personal association with failure and encourages students to strive for

\footnotetext{
${ }^{1}$ Department of Teacher Education, Indiana University South Bend, 1700 Mishawaka Ave, South Bend, IN 46615, jgressic@iusb.edu

${ }^{2}$ Indiana University South Bend, 1700 Mishawaka Ave, South Bend, IN 46615, jblangst@iusb.edu
} 
mastery (Salen \& Zimmerman, 2003). Games offer rewards and immediate feedback that leads to a sense of accomplishment for the player (Kapp, 2012). Moreover, gaming often promotes authentic learning and ample problem-solving opportunities (Gee, 2003). When playing games, individuals are likely to become immersed in the experience and, as a result of this engagement, are more likely to remember information and develop enduring understanding of concepts (Gee, 2003). Through engagement, games afford participants agency and have the potential to prepare them for future learning (Bransford \& Schwartz, 1999). In addition, a study of the social interactions that occur alongside formal gameplay, in online forums, indicates substantial learning and demonstration of scientific habits of mind (Steinkuehler \& Duncan, 2008).

The application of game design principles and elements to non-game contexts, including classroom pedagogy, is broadly defined as gamification (Kapp, 2012). When designing classroom experiences that are inspired by games, there is potential for students to be engaged in their learning and persist in problem solving, much as they would during actual game play. Selfmonitoring and progress tracking through feedback promote self-regulated learning (Zimmerman, 1990). In recent years, gamification has become a widely-adopted pedagogical approach (e.g. Seaborn \& Fels, 2015; Dicheva, Dichev, Agre \& Angelova, 2015). Kapp (2012) and Hamari, Koivisto \& Sarsa (2014) acknowledge, however, that for gamification to truly impact participant learning in positive ways, the integration of game-inspired elements must go beyond superficial integrations like points or badges to focus on deeper structural considerations of games such as "the story, the challenge, the sense of control, decision making, and a sense of mastery" (Kapp, 2012, p. xviii).

In higher education, gamification interventions have been implemented and investigated in multiple formats. While most gamified courses are offered in online environments, Dicheva et al. (2015) indicate face-to-face and hybrid formats have also been explored. The literature indicates that across formats, computer science and game design courses are the most common domains in which gamification occurs (e.g. Sheldon, 2011; Seaborn \& Fels, 2015; Dicheva at al.,, 2015; Barata, Gama, Jorge \& Goncalves, 2013; Ibanez, Di-Serio \& Delgado-Kloos, 2014; Iosup \& Epema, 2014); however, many other domains are also represented.

Gamification efforts have shown positive effects on student engagement, affect, and learning outcomes. For example, Poole, Kemp, Patterson \& Williams (2014) consistently found students were more actively involved and that test scores improved with a gameshow-style approach in undergraduate business courses. Similarly, Iosup \& Epema (2013) found graduate students in a computer science course were more satisfied, successful, and persisted beyond minimum course requirements as a result of gamified interventions. In 2015, Leaning reported similar favorable findings on the use of leaderboards and other game-like activities in a Media Studies undergraduate course.

\section{Gamification and Best Practices}

There are many psychological underpinnings that support gamification as a widely-applicable, effective approach to classroom pedagogy. Despite the amount of theoretical support, in a recent review Seaborn and Fels (2015) found that nearly 90\% of the empirical studies they reviewed on gamification interventions did not explicitly connect to theoretical foundations, but rather focused on the mechanisms. The benefits of gamification, however, align largely with theories of learning and pedagogical best practices. Because of an emphasis on choices, gamification can promote learner agency (Bandura, 1989), which, in turn, motivates students toward mastery goals (Schunk,

Journal of the Scholarship of Teaching and Learning, Vol. 17, No. 3, July 2017. josotl.indiana.edu 
Pintrich, \& Meece, 2008). Further, gamification can scaffold students' self-regulation by providing opportunities to self-monitor performance, which establishes clear expectations and promotes learner accountability.

A primary component that makes games engaging is the underlying story. Because storytelling can potentially restructure how individuals chunk information, it has the potential to promote deeper conceptual meaning which, in turn, leads to more enduring understanding. This leads to more efficient processing and, like expertise within a domain, provides individuals with more sophisticated chunks which represent greater mastery of content (Chi, Feltovich, \& Glaser, 1981).

Another inherently appealing component of games that is useful for educators is the way that games encourage players to persist when they fail. In traditional learning environments, students often lose motivation. One of the main reasons for this is that they feel inferior to peers whom they perceive to be understanding easily (Gee, 2003). Because fear of failure can inhibit students' classroom performance (Dweck \& Leggett, 1988), appropriating approaches from games that promote persistence in problem solving can benefit students' motivation to learn. Game elements like "extra lives", which provide second chances for success, and activities that promote pooling resources are motivating elements that map to classroom learning.

An essential component of a gamified classroom is for students to work collaboratively. In many games, players form guilds (groups of players with similar goals and interests) which encourage collaboration, assistance, and collective intellectual risk-taking. Sheldon (2011) identifies guilds as a cornerstone of gamification. This approach is supported by the theory of small-group cognition, where the small group is considered a unit that accomplishes intellectual outcomes that are a result of social transactions not always possible with individuals (Stahl, 2006). This theory asserts that learners are co-constructing meaning as they work toward the common goal of solving problems in highly integrated ways that move beyond the contribution of any single student. Ideas are more likely to be developed through discourse, leading to more connected, robust understanding of course concepts (Stahl, 2006).

Problem-based learning presents learners with an open-ended, ill-structured, authentic task to complete, which is similar and complementary to problem solving in game play. This approach engages learners with domain knowledge, promotes critical thinking skills (Hmelo \& Evensen, 2000) and serves as a meaningful complementary pedagogy to gamification. Research on problembased learning indicates that, much like game play, it engages learners, offers motivation through choices and collaboration, and leads to an increased, enduring understanding of complex concepts (Albanese \& Mitchell, 1993). Through the use of problem-based, actively collaborative approaches, gamification exemplifies and integrates Kuh’s (2008) high-impact practices.

\section{Gamification in General Educational Psychology}

Aligned with the theoretical and empirical support for gamification, we focus on applying this instructional design approach to a face-to-face undergraduate educational psychology course through a series of systematic, theory-driven innovations designed to optimize student learning. Next, we provide an overview of the context, details of specific elements of gamification, and the results of this approach, including student perceptions of these interventions.

\section{The Context and Problem}

Journal of the Scholarship of Teaching and Learning, Vol. 17, No. 3, July 2017. josotl.indiana.edu 
A common goal across foundational undergraduate courses is for students to develop transferrable knowledge of concepts that they will apply in subsequent courses and in their careers. Because there is an implicit expectation that students will recognize and build upon their understanding in the future, it is imperative that the design of foundational courses prepares students for future learning (Bransford \& Schwartz, 1999).

The course that is the focus of this case study is an introductory 200-level course, General Educational Psychology, offered to undergraduate teacher education students at a public regional state university campus. The data reported below were collected from the Spring 2014 semester. Across two face-to-face courses, 62 students were enrolled and participated in surveys and evaluations.

General Educational Psychology is part of a foundational sequence of courses taken by all teacher education candidates, including elementary, secondary, special education, art education, and music education students. The importance of understanding course concepts extends beyond the final exam; additional courses elaborate on the topics and assume that students will be able to transfer their understanding to other courses and field experiences. The topics of the course include developmental, learning, and motivational theories. Considering this, promoting enduring understanding and preparing students for future learning are essential considerations in this course.

Typically, this course enrolls 30 students per section and has historically been taught in a lecture format guided by Woolfolk's Educational Psychology textbook (2012). Prior to the innovations discussed in this paper, students completed multiple-choice assessments as the primary composition of their course grade. Faculty members grew concerned, however, that students were memorizing rather than understanding, which impeded students' far transfer to other courses, field experience, and state-required licensure exams. This motivated the exploration of alternative, innovative instructional approaches to improve student learning outcomes, engagement, and motivation.

\section{Gamification Innovations to Promote Learning and Engagement}

Gamifying General Educational Psychology involved a series of discrete changes to the course structure, activities, and syllabus. These theory-driven innovations were guided by the framework described above and detailed here. The primary goal was to design a classroom experience that leveraged the deep structure of games to promote students' engagement and understanding (Kapp, 2012).

Storytelling: Scaffolding students’ conceptual knowledge. Kapp (2012), Sheldon (2011) and Gee (2003) all acknowledge the story as an essential element of what makes games engaging. When students entered General Educational Psychology, course content was chunked into three distinct regions of a virtual world map (Figure 1). Since our course covers a wide range of topics, this element of gamification was applied as a means to scaffold students' initial learning and conceptual organization of a variety of sophisticated psychological concepts. For example, at the beginning of the semester, students are transported via rocket ship to the Growing Plains, a region of the EdPsych world. There, they met theorists and interacted with essential course concepts through immersive and collaborative activities designed to promote engagement and enhance students' understanding.

Journal of the Scholarship of Teaching and Learning, Vol. 17, No. 3, July 2017. josotl.indiana.edu 


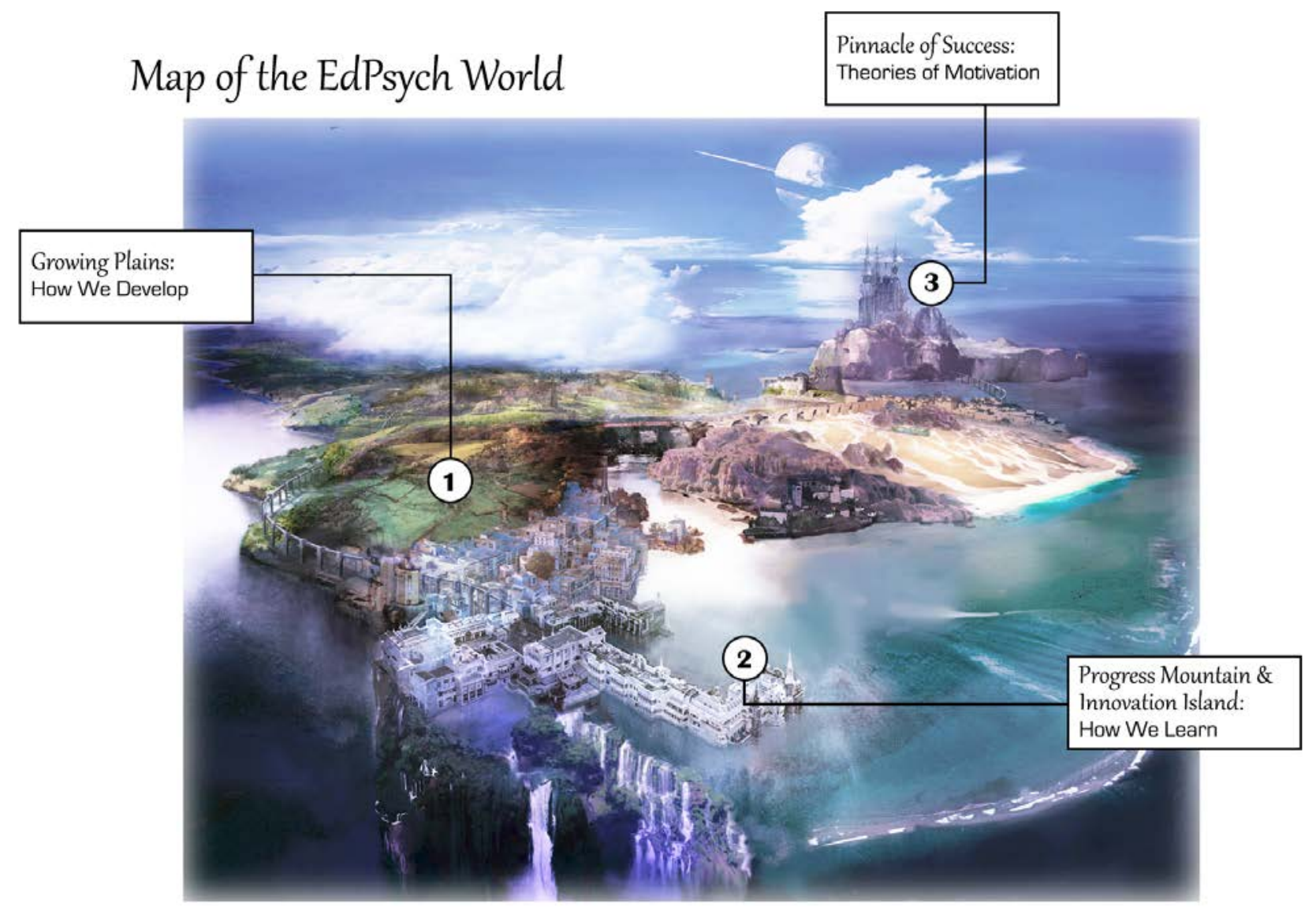

Figure 1. Virtual world map of General Educational Psychology.

Guilds: Strategic grouping to encourage collaboration and community. Another gamification innovation to General Educational Psychology was the introduction of collaborative guilds. We assigned students to guilds of five or six students in which they applied course concepts through problem-based learning (Barrows, 1996; Hmelo-Silver, 2004), analyzing case studies, and playing table top games. Students remained with the same guild all semester, per the recommendation of Sheldon (2011). To assign groups in a way that would encourage discussion, collaboration and intersubjectivity (Nathan, Eilam \& Kim 2007), we created a survey using Google Forms where students shared information about their teaching interests and career goals. Students completed the survey at the beginning of the semester. From survey data, groups were thoughtfully assigned based on common interests. Students were then inducted into their respective guilds and assigned a course-related theorist as a mascot (e.g. Jean Piaget, Lev Vygotsky). Students were assessed periodically by Guild Reports that provided evidence of productivity across these activities. Further, students conducted peer and self- evaluations of performance as a means of group accountability. This provided valuable feedback for the instructor, in case a group experienced problems with shared leadership or group dynamics (Gressick \&Derry, 2010).

In addition to within-guild collaborative activities, students engaged in inter-guild challenges. Since a primary purpose of guilds was to encourage collaboration toward common goals, any competition within class happened between guilds. During these challenges, guilds competed against each other in games and design challenges. For example, students played a traditional Jeopardy review game at the end of the semester where competition was between guilds

Journal of the Scholarship of Teaching and Learning, Vol. 17, No. 3, July 2017. josotl.indiana.edu 
and augmented by texting-in their responses.

Scaffolding self-regulated learning with visualizations. We improved the syllabus for this course following suggestions offered by Sheldon (2011) in his book The Multiplayer Classroom. The revised course syllabus included a gamified approach in how evaluation was articulated and displayed for students. A “leveling up” approach was adopted for course points. Further, visual scaffolds for student grade composition were included (see figure 2). As mentioned above, the syllabus was framed using the metaphor of a virtual world to discuss different sections of course content and to help students "navigate" the broad range of topics covered in this introductory course.

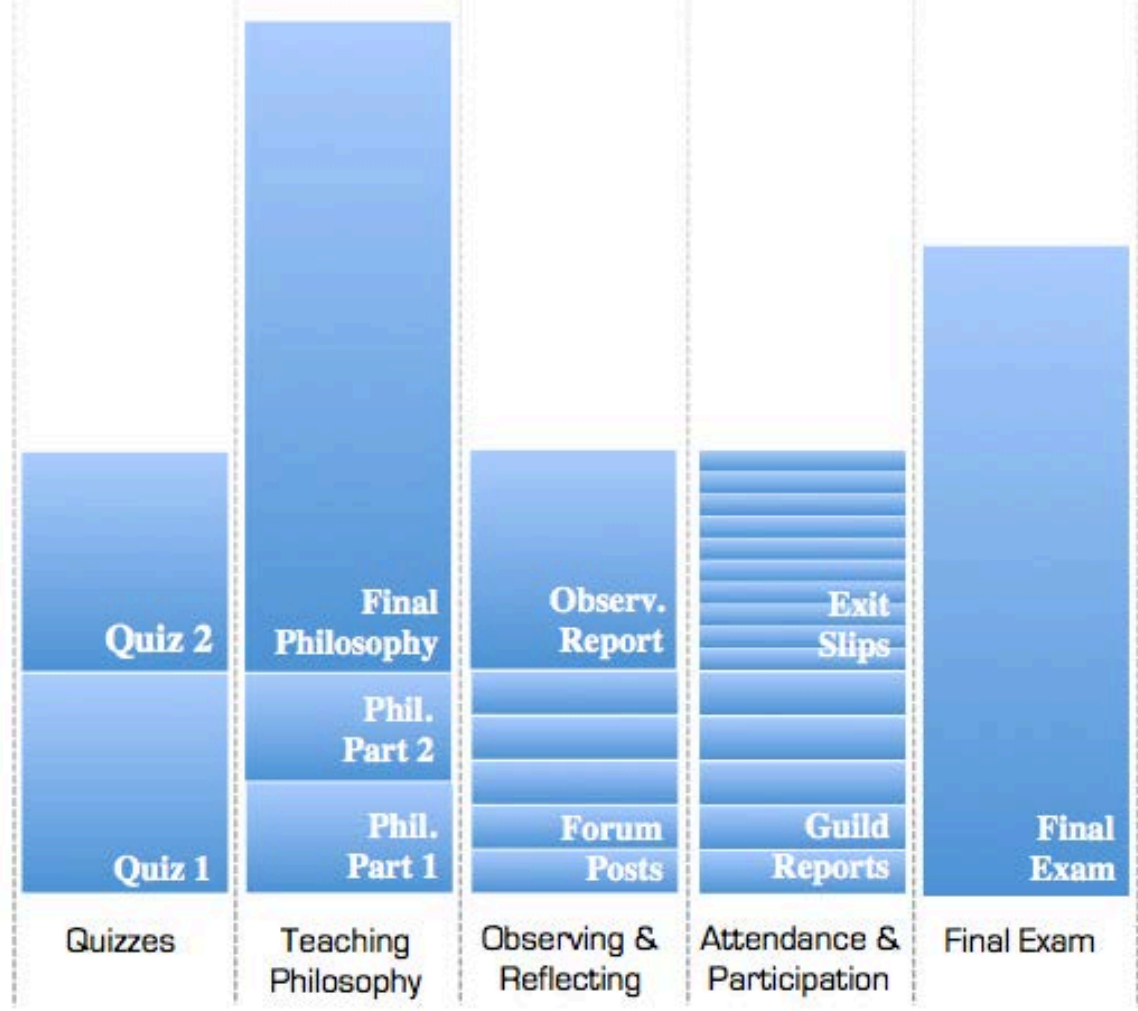

Figure 2. Visual representation of course grade composition.

Discrete Games to Engage Learners. Throughout the semester, guilds learned through a variety of activities. In addition to collaboratively applying concepts to written case studies and problem-based learning, students participated in discrete games. Two of the games used in the course are highlighted next.

The first game students played was called Erikson's Psychosocial Development Card Game: An Inter-Guild Challenge. Students worked with their guilds to understand Erik Erikson's stages of psychosocial development (Erikson, 1963). The objective of the game was for individuals within a group to reach consensus over which stage of Erikson's theory was represented in a scenario and to determine whether a positive or negative resolution had been established. Each guild member received a set of cards printed with Erikson's 8 stages of development and a “+” and "-“" card to indicate positive or negative resolution of the crises associated with the stages. Each guild also received a set of "scenario" cards. A player would read the scenario and each guild member would select the stage and resolution card they thought was represented by the scenario.

Journal of the Scholarship of Teaching and Learning, Vol. 17, No. 3, July 2017. josotl.indiana.edu 
Guilds then discussed, reached consensus, and recorded their agreed-upon response and justification. The entire class then discussed their responses and scores were kept at the guild level. A secondary goal of this game was to encourage negotiation and collaboration within guilds.

Students also participated in a $Q R$ Code Scavenger Hunt. In this review game, students worked with their guild to find and answer questions about course concepts. QR codes that linked to the questions were hidden throughout a campus building near classrooms and offices. When students scanned a code, they were linked to questions hosted by Google Forms. When guilds submitted a response, they were directed to a new location in the building. If a guild's response was correct, they would find another QR code to scan in the new location. If they were incorrect, they would not find a new code and attempt the question again, until they were directed to the location associated with the correct response and a new code. The first guild to finish won the game. Data from students' responses were logged in a spreadsheet. This provided evidence of student performance and revealed concepts that needed further review (Gressick, Spitzer, \& Sagarsee, 2014).

Promoting Perseverance with "Extra lives": Virtual 1Up learning opportunities. As mentioned above, a motivating element in games is the opportunity for players to experience multiple paths to success. Considering this, we developed activities that allow students to earn additional points toward assignments. The goal of these activities was to promote student meaningmaking by encouraging connections to popular culture. For example, one series of activities engaged students in "thinking with" course concepts by applying them to various films. Throughout the semester, students could earn extra lives by engaging in analysis of popular films as a way to make meaning of course concepts. For example, students could analyze the movie Cast Away (Zemeckis, 2000) in terms of object affordances, environmental constraints, and creative problem solving. Similarly, students could earn 1 Up points by using developmental theories to describe social roles and patterns of behavior in Mean Girls (Michaels, 2004). These opportunities afforded students agency to both choose learning opportunities and control the points they earned for the class. Further, this approach was adopted to help promote student success, innovative thinking on assessments, and to ultimately encourage a shift in goal orientation from grade-driven performance to mastery understanding of content knowledge (Schunk, Pintrich, \& Meece, 2008).

\section{Methodology}

To understand the impact of the aforementioned innovations on student learning, we leveraged a case study approach, where the effects of theory-driven classroom gamification innovations were observed in the authentic context in which they occurred (Yin, 2009). Adopting this approach and collecting data from multiple resources was motivated by our desire to formulate an in-depth understanding of implementing gamification in the classroom. Further, the interventions are an inherent part of the class structure similar to how underlying structures in games support motivation and engagement. Therefore, to gain organic insights on the effectiveness of this approach, it was essential to study this phenomenon within its authentic context.

\section{Data Sources}

Data were collected from two General Educational Psychology courses taught in the spring semester of 2014 at a Midwestern regional state university campus. The courses were both taught by the same instructor and were identical in terms of content and delivery. The classes were

Journal of the Scholarship of Teaching and Learning, Vol. 17, No. 3, July 2017. josotl.indiana.edu 
approximately the same size and enrolled a total of 62 students. Multiple sources of data, as described below, were collected and synthesized to build understanding of how gamification approaches influenced students’ learning experiences.

Initial Student Survey. At the beginning of the semester students completed an individual online survey for the instructor. Data were used to thoughtfully group students into collaborative guilds and to establish their baseline understanding and motivation about educational psychology and teaching.

Mid-semester Guild Progress Evaluations. As part of guild activity, students completed self and peer evaluations that were guided by participation norms and distributed leadership expectations (Gressick \& Derry, 2010). Students responded to the following questions using a 4point scale, where they rated the following questions as High (4), Mostly (3), Somewhat (2) Low (1), not demonstrated (0):

1. Did this person make sufficient contributions?

2. Did they actively participate in your guild's discussions?

3. Was this person a good group citizen, taking on some leadership? (i.e., helping keep the group on task, helping to problem solve, contributing positive and encouraging words to others)

Students rated their peers anonymously and were encouraged to write comments about the overall guild operation and specific members.

Student Reflection Survey. At the end of the semester, students completed a brief survey that was designed to collect information and gain understanding of students' perceptions of the applied gamification principles in General Educational Psychology. Paper surveys were administered to students during the last day the course met. Students were asked to anonymously rate the effectiveness of the syllabus format, working in guilds, and in-class games.

Course grades. Grades from the Spring 2014 semester were compared with the Spring 2013 semester course taught by the same instructor. In Spring 2014 General Educational Psychology enrolled 57 students. Overall course averages were compared across semesters to assess whether the gamification interventions improved students' academic success. The previous class had been taught using traditional lecture and multiple-choice question assessments.

Unsolicited student feedback. Students completed official university-administered evaluations of General Educational Psychology at the end of the semester. Along with numerical ratings, students have an opportunity to provide qualitative comments on the course. Relevant comments are discussed in the results section below. Follow-up, unsolicited email correspondence from students about the gamified course are also included in the results section below.

Instructor observations of student learning. In addition to collecting data from students, the course instructor kept a detailed reflective journal of her perception of the impact of gamification strategies on student learning. The focus of this journal was on student interaction and engagement during guild activities. We analyzed the journal for themes about the instructor's perceptions of the interventions.

Journal of the Scholarship of Teaching and Learning, Vol. 17, No. 3, July 2017. josotl.indiana.edu 


\section{Results and Discussion}

We collected data from a variety of sources to address our general research question centered on the effectiveness of the described gamification innovations on student learning, engagement, and perception of the course. Overall, the results of gamification were positive.

\section{Mid-semester Guild Progress Evaluations}

We calculated the average for each individual's scores resulting from peer rating and the average across group members for each guild. The results of the mid-semester guild progress evaluations are provided in Table 1. Results indicate a high level of participation across group members and a positive perception of peers within guilds. Most guilds received unanimous high ratings across guild members, which suggests a strong sense of community within the groups. The lowest acrossmember, within-guild average was in Group $\mathrm{H}$ from Class Section 2. On closer analysis of student surveys, the group's average was lower because of a single guild member who was absent and, when present, spent all of their time off task. One student wrote that the member was constantly on their smartphone rather than engaged in guild discourse. Interestingly, this didn't influence other ratings within the guild. The results of these evaluations allowed for an opportunity for the instructor to provide additional support for that group's distribution of leadership and engagement.

Table 1. Mid-semester guild progress evaluations

\begin{tabular}{|c|c|c|c|c|c|c|c|c|c|c|c|c|}
\hline & \multicolumn{12}{|c|}{ Guild Average Ratings } \\
\hline & \multicolumn{6}{|c|}{ Class Section 1} & \multicolumn{6}{|c|}{ Class Section 2} \\
\hline & A & $\mathrm{B}$ & $\mathrm{C}$ & $\mathrm{D}$ & $\mathrm{E}$ & $\mathrm{F}$ & $\mathrm{G}$ & $\mathrm{H}$ & I & $\mathrm{J}$ & $\mathrm{K}$ & $\mathrm{L}$ \\
\hline Question 1 & 4 & 4 & 4 & 3.8 & 4 & 4 & 4 & 3.5 & 3.8 & 4 & 4 & 4 \\
\hline Question 2 & 4 & 4 & 4 & 3.8 & 4 & 4 & 4 & 3.5 & 3.8 & 4 & 4 & 4 \\
\hline Question 3 & 4 & 4 & 3.8 & 3.8 & 4 & 4 & 4 & 3.5 & 3.8 & 4 & 4 & 4 \\
\hline
\end{tabular}

Students were encouraged to write comments along with providing numerical ratings. Of the 62 students who participated, 13 provided written comments along with their numerical ratings. Most of the comments students provided indicated that they enjoyed working with their Guild (e.g. "I felt like we all worked well together”).

\section{Student Reflection Questionnaire}

Overall, students responded positively, both affectively and academically, to the gamification innovations described above. At the end of the semester students completed a brief, anonymous survey about these innovations (see Table 2). Sixty-two students completed the survey. The general prompt students received on the survey was: This course includes instructional approaches that relate to gaming. Indicate your satisfaction with the following elements of this, relative to how you feel they helped you learn.

\section{Table 2. Student reflection questionnaire results}

Journal of the Scholarship of Teaching and Learning, Vol. 17, No. 3, July 2017. josotl.indiana.edu 


\begin{tabular}{llllll}
\hline & $\begin{array}{l}\text { Really } \\
\text { Helped (4) }\end{array}$ & $\begin{array}{l}\text { Somewhat } \\
\text { Helped (3) }\end{array}$ & $\begin{array}{l}\text { Didn’t Impact } \\
\text { My Learning } \\
(2)\end{array}$ & $\begin{array}{l}\text { Minimally } \\
\text { Helped Me (1) }\end{array}$ & Not at All (0) \\
\hline $\begin{array}{l}\text { Syllabus } \\
\text { Format }\end{array}$ & $14(23 \%)$ & $39(63 \%)$ & $7(11 \%)$ & $2(3 \%)$ & -- \\
$\begin{array}{l}\text { Working in } \\
\text { Guilds }\end{array}$ & $35(56 \%)$ & $26(42 \%)$ & -- & $1(\sim 2 \%)$ & - \\
$\begin{array}{l}\text { In-class } \\
\text { Games }\end{array}$ & $47(76 \%)$ & $15(24 \%)$ & -- & -- & - \\
\hline $\mathrm{n}=62$ & & & & &
\end{tabular}

Survey results indicate that students felt the syllabus format and in-class games helped them learn. 23\% of students indicated they found the syllabus format highly helpful and an additional $63 \%$ of student indicated the format was somewhat helpful. More than half of the students indicated that working in guilds really helped their learning and $42 \%$ indicated this gamification feature as somewhat helpful. In addition, students unanimously indicated that in-class games helped them to learn, with $76 \%$ of students indicating this approach as highly helpful. Overall, the survey results indicate that students positively perceived the General Educational Psychology gamification interventions. These results are supported by unsolicited qualitative comments reported below.

\section{Course Grades}

We compared final student course averages from Spring 2014 with a previous, traditionally-taught semester to provide a quantified overview of students' success in gamified General Educational Psychology. The average student score in the gamified course sections was $95.16 \%(\mathrm{SD}=4.15)$. The average student score in a previous semester was $87.26 \%(\mathrm{SD}=6.52)$. Students' averages in the gamified sections of General Educational Psychology were significantly higher than the previous lecture sections, $t(117)=7.95, p<.001$. This indicates that the overall gamified approach led to higher summative student achievement.

\section{Unsolicited student feedback}

In addition to the reflection questionnaire distributed at the end of the semester by the course instructor, students provided unsolicited comments on the University's official course evaluations. Table 3 provides evidence of students' unprompted perceptions of the innovations.

\section{Table 3. Student comments about gamification interventions on official course evaluations}

By putting everyone into guilds we were forced to get along with the other students but because the learning environment was so positive this was not a problem

I was unsure as why we were broken down in "guilds" or groups at first. but after our first group assignment I began to like the group time, it made me understand [course] terms better, if I was off track a bit. Even though I did have a quiet group, these group activities were fun.

Journal of the Scholarship of Teaching and Learning, Vol. 17, No. 3, July 2017. josotl.indiana.edu 
I would have to say placing us in designated groups made class so much more enjoyable, and it forced us to interact with others in the class, and I made some new friends.

The learning environment was great I liked the guild activities because they helped open up the class and get to know people.

It was a comfortable environment where we could open up and voice our opinions. I think the guilds also contributed to that because we had our own groups that were always the same so we could really communicate well rather than choosing from the whole class.

[the professor] eliminates as much stimuli as possible and has us set up in guilds. I must say my guild is the best and [the professor] knew what she was doing when she set us up in guilds because I feel I am walking away with lifelong friends.

I feel as if the Guild Teams really brought everyone together to learn and create strong social bonds. These teams also broke many of the barriers that impede learning in a lecture-style classroom.

I love the layout in the syllabus

There are many places that you can keep track of your grades in this class, it is very helpful

The sample student comments supplied in Table 2 suggest that the interventions had a meaningful impact on their learning. These comments echo the perception of the guild structure that students communicated at the mid-semester guild progress evaluations, reported above. The course also received high numerical ratings overall, with an average of 1.12 , where $1=$ "strongly agree" with desired criteria and 5 = "strongly disagree."

In addition to comments from students supplied on the course evaluations, the instructor received multiple unsolicited follow-up emails from students in semesters after the course ended, indicating the impact the course had on their enduring understanding of concepts and how it prepared them for future learning. Three examples are illustrated in table 4.

\section{Table 4. Sample emails received from students after the course ended}

... I thought you might like to hear this. I was reading my textbook for [other education class] and ran across several key terms from your class. I know you told us that this would happen and I was expecting it. What surprised me wasn't that they were there, but that I didn't even skip a beat when it came to understanding what it meant!

And it just hit me all of a sudden that I understood all of it with perfect clarity, and it made me realize I actually learned something from [General Educational Psychology] that stemmed beyond the course. It was an awesome feeling. So just thought I'd drop you an email letting you know (:

You will not believe this, but I am taking [other education class] and during class he mentioned ALL of the following things, which I remembered from your class and totally understood:

-The ZPD

-Vygotsky and Piaget

-Piaget's stages of development (!!!!)

-Cognitive, moral, and social development

-Scaffolding

-Erik Erikson's 8 stages of psychosocial development

Journal of the Scholarship of Teaching and Learning, Vol. 17, No. 3, July 2017. josotl.indiana.edu 
Unsolicited feedback received both immediately on official university course evaluations after the course ended and through emails from students received months after the course was over indicate that students enjoyed the course, felt engaged in learning, and developed enduring understanding of course concepts.

\section{Instructor observations of student learning}

Along with soliciting feedback from students on the gamification of General Educational Psychology, the course instructor kept a reflective journal throughout the semester on her perception of student learning and engagement. The instructor observed that students were more actively engaged within small group discussions, indicating that the classroom was often filled with talking and laughter. The instructor observed that students enjoyed working with their guilds and this approach promoted a positive, collaborative learning environment. While attendance was not factored into students' course grades, the instructor noted that attendance was consistently high throughout the semester. Another recurring theme was the positive classroom climate where students seemed focused on learning and future growth rather than getting caught up on their mistakes. These observations offer direct support for the students' perception of the interventions.

\section{Conclusion}

As evidenced by the data above, the theory-driven gamification of General Educational Psychology was, overall, a successful innovation. Student survey data and comments indicate that, from a student perspective, the innovations to the course were valued and encouraged learning, collaboration, and peer contacts. From an instructor perspective, the gamification elements promoted student learning and enhanced the classroom climate. Unsolicited feedback from students suggests their learning experiences promoted enduring understanding.

Overall, students enjoyed working in guilds. Students were thoughtfully grouped and were supported through clear expectations and opportunities to provide peer feedback on fellow guild members. As indicated in the results section, one group self-reported some challenges. A future consideration will be to develop interventions to help groups self-diagnose and remedy social challenges that may impede group learning (Barron, 2003).

The grades within gamified sections of General Educational Psychology were significantly higher than a traditionally-taught section of the class. Similar to the findings of Iosup and Epema (2013), this suggests students were willing to go above and beyond minimal course expectations and that thoughtful gamification interventions potentially promote persistence in learning.

We recognize there are limitations to our study. Having never been taught through gamification practices, we could not rely on our own experiences as students to help inform best practices in this intervention. Instead we relied heavily on those that had gone before. This presents an interesting challenge for many educators who would attempt the use of gamification in their classrooms, as, unlike most pedagogical approaches, instructors have very little to no personal experience off which to model this new process. Since this course enrolled future educators, modeling innovation is important to encourage future teachers to take theoretically-informed instructional risks, which means these students will have had the experience that most gamification innovators lack. The students in the class experienced the vicarious impact of these interventions on their own learning (Bandura, 1989).

Journal of the Scholarship of Teaching and Learning, Vol. 17, No. 3, July 2017. josotl.indiana.edu 
Further, as Seaborn and Fels (2015) suggest in their investigation of gamification as a whole, the concepts and practices of gamification are by no means monolithic in nature. Our work adds to the theoretical and empirical body of support for the use of games and gamification in the undergraduate classroom. Because of the general nature of the gamification interventions described in this paper, they could easily be adapted to various contexts, even outside of formal education. Moreover, gamification elements, like guilds, storytelling, and leveling up, can be adopted individually to support specific learning objectives.

\section{References}

Albanese, M. A., \& Mitchell, S. (1993). Problem-based learning: a review of literature on its outcomes and implementation issues. Academic Medicine, 68, 52-81.

Barata, G., Gama, S., Jorge, J., \& Gonçalves, D. (2013, October). Improving participation and learning with gamification. In Proceedings of the First International Conference on Gameful Design, Research, and Applications (pp. 10-17). ACM.

Barron, B. (2003). When smart groups fail. Journal of the Learning Sciences, 12(3), 307-359. doi: 10.1207/S15327809JLS1203_1

Barrows, H. S. (1996). "Problem-based learning in medicine and beyond: A brief overview". New Directions for Teaching and Learning (68): 3. doi: 10.1002/tl.37219966804

Bransford, J. D., \& Schwartz, D. L. (1999). Rethinking transfer: A simple proposal with multiple implications. In A. Iran-Nejad \& P. D. Pearson (Eds.), Review of Research in Education , 24, 61101. Washington DC: American Educational Research Association. doi: 10.3102/0091732X024001061

Chi, M. T. H., Feltovich, P. J., \& Glaser, R. (1981). Categorization and representation of physics problems by experts and novices. Cognitive Science 5, 121-152. doi: 10.1207/s15516709cog0502_2

Derry, S. J., Siegel, M., Stampen, J., and the STEP team (2002). The STEP system for collaborative case-based teacher education: Design, evaluation, and future directions. In Stahl, G. (ed.), Proceedings of CSCL 2002, Erlbaum, Hillsdale, NJ, pp. 209-216.

Dicheva, D., Dichev, C., Agre, G., \& Angelova, G. (2015). Gamification in education: a systematic mapping study. Educational Technology \& Society,18(3), 1-14.

Dweck, C. S., \& Leggett, E. L. (1988). A social-cognitive approach to motivation and personality. Psychological review, 95(2), 256. doi: 10.1037/0033-295X.95.2.256

Erikson, E. H. (1950). Childhood and society (2nd ed.). New York, NY: Norton.

Gee, J. (2003). What video games have to teach us about learning and literacy (2 ${ }^{\text {nd }}$ ed.). Houndmills, Basingstoke, Hampshire, England; Palgrave Macmillan.

Journal of the Scholarship of Teaching and Learning, Vol. 17, No. 3, July 2017. josotl.indiana.edu 
Gressick, J. \& Derry, S.J. (2010). Distributed leadership in online groups. International Journal of Computer-Supported Collaborative Learning (ijCSCL) Vol. 5, Number 2.

Gressick, J., Spitzer, B.A, \& Sagarsee, K. (2014). Designing Interactive Scavenger Hunts Using QR Codes. Journal of Teaching and Learning with Technology (JoTLT) 3(1). doi: 10.14434.jotlt.v3n1.4239

Hamari, J., Koivisto, J. \& Sarsa, H. (2014). Does gamification work? A literature review of empirical studies on gamification. Proceedings of the 47th Hawaii International Conference on System Science (pp. 3025 - 3034). doi: 10.1109/HICSS.2014.377

Hmelo-Silver, C. E. (2004). Problem-based learning: What and how do students learn? Educational Psychology Review, 16, (3), 235-266.

Hmelo, C. E., \& Evensen, D. H. (2000). Problem-based learning: Gaining insights on learning interactions through multiple methods of inquiry. Problem-based learning: A Research Perspective on Learning Interactions, 1-16.

Ibanez, M. B., Di-Serio, A., \& Delgado-Kloos, C. (2014). Gamification for engaging computer science students in learning activities: A case study. Learning Technologies, IEEE Transactions on, 7(3), 291-301.

Iosup, A., \& Epema, D. (2014). An experience report on using gamification in technical higher education. In Proceedings of the 45th ACM technical symposium on Computer science education. (pp. 27-32). ACM.

Iosup, A., \& Epema, D. (2013). On the gamification of a graduate course on cloud computing. In The International Conference for High Performance Computing, Networking, Storage and Analysis. IEEE.

Kapp, K. M. (2012). The gamification of learning and instruction: Game-based methods and strategies for training and education. San Francisco: Pfeiffer.

Leaning, M. (2015). A study of the use of games and gamification to enhance student engagement, experience and achievement on a theory-based course of an undergraduate media degree. Journal of Media Practice, 16(2), 155-170.

Michaels, L. (Producer), \& Waters, M. (Director). (2004). Mean girls [Motion picture]. United States: Paramount Pictures.

Kuh, G. D. (2008). High-impact educational practices: What they are, who has access to them, and why they matter. Washington, DC: Association of American Colleges and Universities.

Nathan, M. J., Eilam, B., \& Kim, S. (2007). To disagree, we must also agree: How intersubjectivity structures and perpetuates discourse in a mathematics classroom. The Journal of the Learning Sciences, 16(4), 523-563.

Journal of the Scholarship of Teaching and Learning, Vol. 17, No. 3, July 2017. josotl.indiana.edu 
Poole, S. M., Kemp, E., Williams, K. H., \& Patterson, L. (2014). Get your head in the game: Using gamification in business education to connect with Generation Y. Journal for Excellence in Business Education, 3(2).

Pugh, K. J. \& Bergin, D. A. (2006). Motivational influences on transfer. Educational Psychologist, 41, 147 - 160. DOI:10.1207/s15326985ep4103_2

Salen, K. \& Zimmerman, E. (2003). Rules of play: Game design fundamentals. The MIT Press.

Schunk, D. H., Pintrich, P. R., \& Meece, J. L. (2008). Motivation in education: Theory, research, and applications ( $3^{\text {rd }}$ ed.). Columbus, $\mathrm{OH}$ : Merrill.

Seaborn, K., \& Fels, D. I. (2015). Gamification in theory and action: A survey. International Journal of Human-Computer Studies, 74, 14-31. doi: 10.1016/j.ijhcs.2014.09.006

Sheldon, L. (2011). The multiplayer classroom: Designing coursework as a game. Cengage Learning PTR.

Stahl, G. (2006). Group cognition: Computer support for building collaborative knowledge. MIT Press.

Steinkuehler, C. \& Duncan, S. (2008). Scientific habits of mind in virtual worlds. Journal of Science Education and Technology, 17, (6), 530-543. doi: 10.1007/s10956-008-9120-8

Woolfolk, A. E. (2012). Educational psychology, (12 ${ }^{\text {th }}$ ed.). Englewood Cliffs, N.J.: Prentice Hall, Inc.

Yin, R. K. (2009). Case study research: Design and methods (4th ed.). Thousand Oaks, CA: Sage. Zemeckis, R. (Director). (2000). Cast away [Motion picture]. United States: $20^{\text {th }}$ Century Fox. Zimmerman, B. J. (1990). Self-regulated learning and academic achievement: An overview. Educational Psychologist, 25(1), 3 - 17. doi: 10.1207/s15326985ep2501_2

Journal of the Scholarship of Teaching and Learning, Vol. 17, No. 3, July 2017. josotl.indiana.edu 